\title{
Giant spinal exostosis
}

\section{Chandramohan Sharma, Mihir Acharya, Bansi Lal Kumawat, Jigar Parekh}

Department of Neurology, Sawai Mansingh Medical College and Hospital, Jaipur, Rajasthan, India

\section{Correspondence to} Professor Chandramohan Sharma,

cmsharma65@hotmail.com

Accepted 17 March 2014
CrossMark

\footnotetext{
To cite: Sharma C, Acharya $\mathrm{M}$, Kumawat $\mathrm{BL}$, et al. BMJ Case Rep Published online: [please include Day Month Year] doi:10.1136/bcr-2014203819
}

\section{DESCRIPTION}

A 20-year-old man presented with an 11-year history of insidious onset gradually progressive, painless swelling at the nape of the neck. The swelling had been asymptomatic all these years, except for its peculiar appearance. On examination the cervical region swelling was non-tender, bony, hard and immobile with normal overlying skin and no restriction of neck movements (figure 1). There were no focal neurological deficits. CT of the cervical spine showed a large exostosis of the posterior spinous processes of C7 and T1 vertebrae (figure 2). The patient was managed with surgical resection of the exostosis and excision histopathology confirmed the diagnosis of osteochondroma.

Exostosis, also called osteochondroma, is considered the most common benign tumour of the bone, with low rate of malignant degeneration between $1 \%$ and $5 \%$. Spinal exostoses ${ }^{1}$ are uncommon, accounting for 1-9\% of all exostoses. Within the spine, the lesions almost always occur in the posterior elements, ${ }^{2}$ hence spinal cord compression is rare. Solitary lesions affect the cervical spine most commonly with a predilection for the atlantoaxial area, followed by the thoracic spine, and then the lumbar region. CT scan is the imaging modality of choice for these lesions. Treatment usually involves

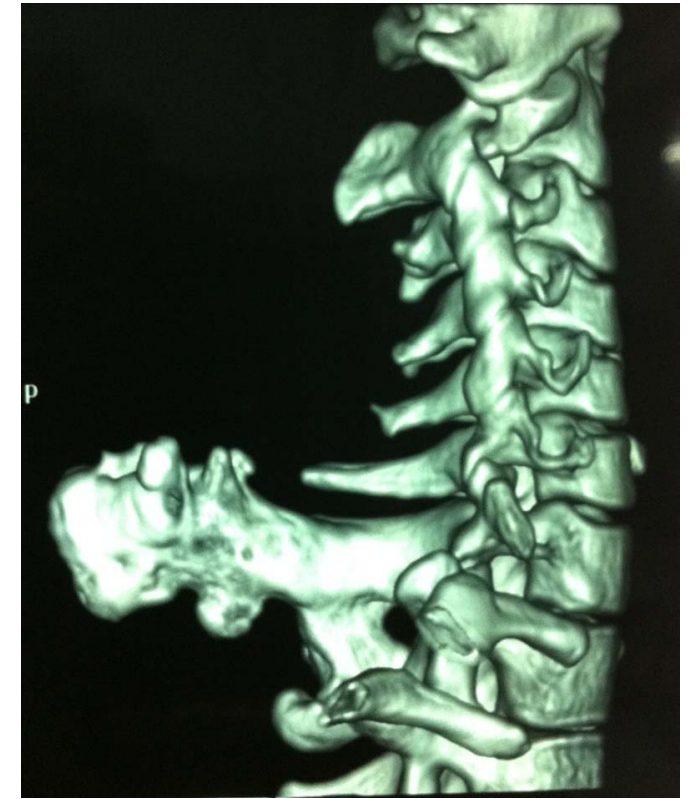

Figure 2 Reconstructed sagittal CT of the cervical spine - giant exostosis of the posterior spinous processes of C7 and T1-weighted vertebrae.

surgical resection, especially for symptomatic patients with pain or neurological deficits such as

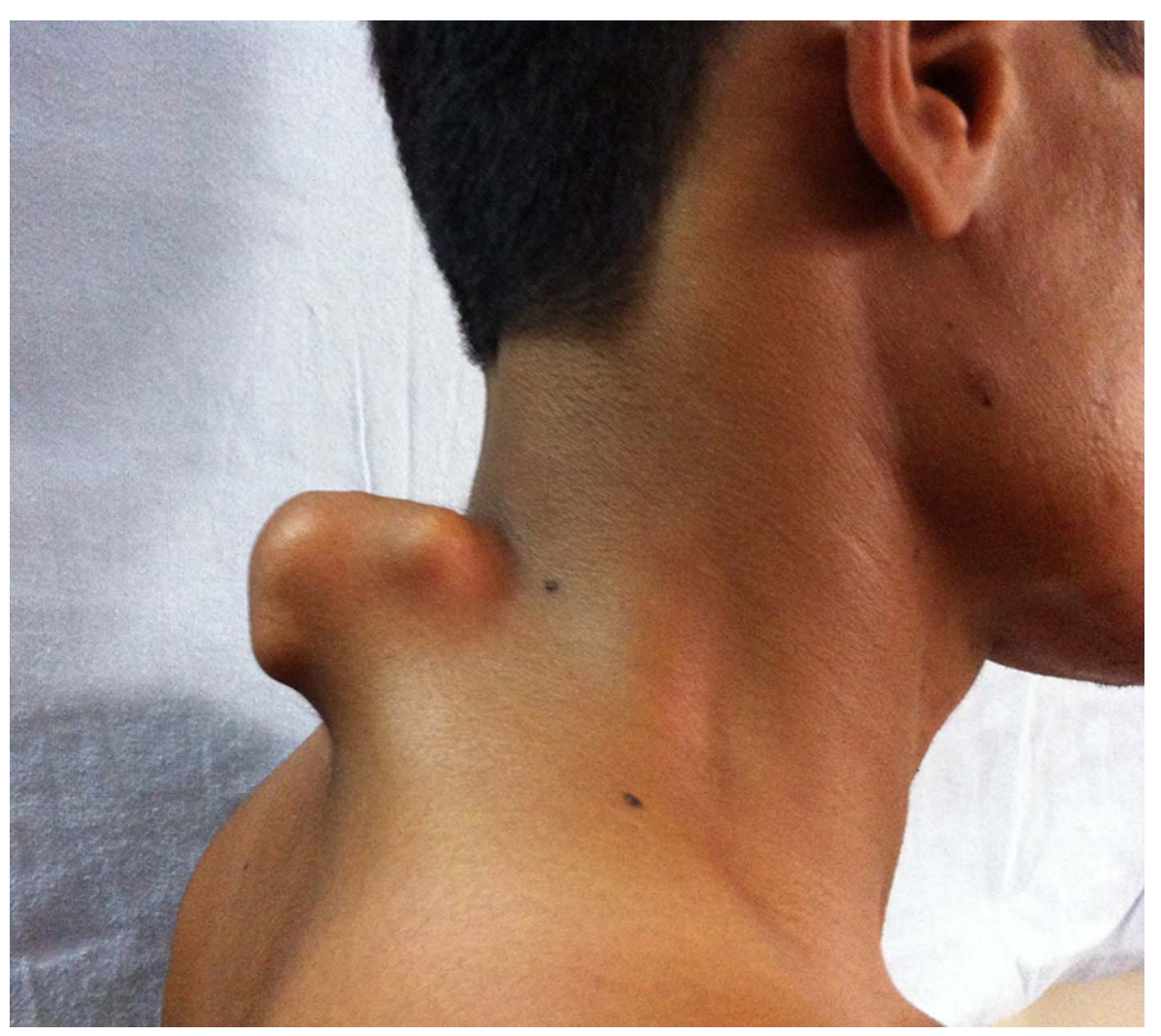

Figure 1 Giant cervical spine exostosis—hard, bony, immobile and non-tender swelling at the nape of neck. 
paraparesis, or for cosmetic reasons. Recurrence rate is low. Hence, the rarity of this tumour at this location, with such a large size, makes this article unique.

\section{Learning points}

- Exostoses are benign bone tumours, which may rarely occur in the spinal vertebrae, affecting the posterior elements.

- Usually asymptomatic, but they may cause focal pain or neurological symptoms such as paraparesis.

- CT scan is the investigative modality of choice and surgical resection is the treatment modality of choice.
Contributors The four authors contributed to the planning, conduct and reporting of the work described in the article and are justifiably credited with authorship, according to the authorship criteria. All authors read and approved the final manuscript. CS is the guarantor.

Competing interests None.

Patient consent Obtained.

Provenance and peer review Not commissioned; externally peer reviewed.

\section{REFERENCES}

1 Abbas $\mathrm{M}$, Khan $\mathrm{AQ}$, Siddiqui $\mathrm{YS}$, et al. Young adult and giant cervical exostosis. Saudi Med I 2011;32:80-2.

2 Rao H, Jakheria S. Giant cervical exostosis: a case report with review of literature. J Pediatr Orthop B 2009;18:103-5.

Copyright 2014 BMJ Publishing Group. All rights reserved. For permission to reuse any of this content visit http://group.bmj.com/group/rights-licensing/permissions.

BMJ Case Report Fellows may re-use this article for personal use and teaching without any further permission.

Become a Fellow of BMJ Case Reports today and you can:

- Submit as many cases as you like

- Enjoy fast sympathetic peer review and rapid publication of accepted articles

- Access all the published articles

- Re-use any of the published material for personal use and teaching without further permission

For information on Institutional Fellowships contact consortiasales@bmjgroup.com

Visit casereports.bmj.com for more articles like this and to become a Fellow 